Covered in: Web of Sciences (WOS); EBSCO; ERIH+; Google Scholar; Index Copernicus; Ideas RePeC; Econpapers; Socionet; CEEOL; Ulrich ProQuest; Cabell, Journalseek; Scipio; Philpapers; SHERPA/RoMEO repositories; KVK; WorldCat; CrossRef; CrossCheck

2018, Volume 10, Issue 4, pages: 156-165 | doi: https://doi.org/10.18662/rrem/79

\section{Perceptions and} Attitudes of Teaching Staff in Relation to Discriminatory Practices in

\section{Romanian Schools}

\section{Laura Monica GORGHIU1,} Ana-Maria Aurelia PETRESCU2, Gabriel GORGHIU3, Roxana Constanța ENACHE 4

${ }^{1}$ Associated professor, Valahia University Targoviste, Romania,

laura.gorghiu@valahia.ro

${ }^{2}$ Associated professor, Valahia University Targoviste, Romania, anapetrescu2007@yahoo.com

${ }^{3}$ Associated professor, Valahia University Targoviste, Romania, ggorghiu@gmail.com

${ }^{4}$ Associated professor, Technical University of Civil Engineering Bucharest, Romania, rocatare@yahoo.com
Abstract: Nowadays, more and more people consider diversity as an opportunity and a strong resource which should be used appropriately as a basis for intercultural education seen as a key-factor, on the one hand for the stability of the society and its increased chances to be developed in a sustainable way, teaching us how to cohabit, and on the other hand for promoting equality, respect and openness towards communicating with others. In this respect, the actual school takes over and duplicates the socially validated practices that relate inclusively to the issues of interculturalism and discrimination, based on various criteria represented by gender, ethnicity, religion, level of development, social, cultural and economic status etc. Although there are education policies which obviously promote a series of principles concerning equal chances, irrespective of social origins, gender, age, ethnicity, religion etc., in reality, the education faces up - even nowadays - a series of segregationist and discriminatory practices. This paper aims to retrieve a part of primary and secondary teachers' opinions concerning the forms of discrimination which are present in schools and classes, but also their attitudes related to such discriminatory practices, being completed with several solutions for fighting and diminishing those undesirable behaviors. More, the results of the microresearch have in view to determine teachers to adopt a reflective attitude concerning sensitive issues related to the discriminatory practices still met in the Romanian schools. Additionally, some examples of good education practices on fighting and preventing of any type of discrimination are underlined.

Keywords: discrimination; equal opportunities; interculturality; teachers'perceptions and attitudes.

How to cite: Gorghiu, L. M., Petrescu, A.-M. A., Gorghiu, G., \& Enache R.C. (2018). Perceptions and Attitudes of Teaching Staff in Relation to Discriminatory Practices in Romanian Schools. Revista Romaneasca pentru Educatie Multidimensionala, 10(4), 156-165.

https://doi.org/10.18662/rrem/79 


\section{Introduction}

During the past decades, concepts such as discrimination together with non-discrimination, equality of chances and intercultural education are more and more often used by civil society in general, and in the education environment in particular. Contemporary societies are "pluralistic from an ethnic and cultural standpoint, and as far as identities and interests are concerned have become the place where various more and more prominent and vocal diversities live together." (Ivasiuc, Koreck, \& Kovari, 2010: 11).

Therefore, the education organization, as an institution that tends to perpetuate and sometimes highlight a series of theories and practices stated socially, needs to be prepared through teachers, acting as change promoters, to cope with the current and future requirements of the society.

Usually, discrimination means "any distinction, exclusion, restriction or preference based on race, nationality, ethnicity, language, religion, social status, convictions, gender, sexual orientation, age, handicap, chronical contagious disease, HIV, belonging to a destitute category, as well as on any other criterion that has as a purpose or consequence the limitation or probibition of recognition, usage or exercise of the human rights and fundamental liberties or rights acknowledged by law, in the political, economic, social and cultural area or in any other area of public life." (Law no. 324/2006, art. 2. paragraph 1).

\section{Problem Statement}

In terms of both conviction and attitude manifested at the behavior level, discrimination is based on a series of convictions (most of the times irrational or unacknowledged), stereotypes and prejudices, regarding those that are different than most of the people. Discrimination criteria vary ranging from race, nationality or ethnicity to language, religion, social status, gender, sexual orientation, age, a certain disease or disability etc. In other cases, discrimination is based on deeper factors, such as convictions, attitudes, values, believes etc.

The National Council for Combating Discrimination in Romania identifies several discrimination forms, also found in schools (CNCD, n.d.):

- Direct discrimination - happens "when a person is treated less favorably than another person that was, is or might be in a similar situation, the difference in treatment being based on any of the discrimination criteria provided by the law in force" (e.g. discriminating a student based on criteria related to social category or a certain disability);

- Indirect discrimination - happens "when an apparently neutral provision, criterion or practice disadvantages certain persons"; although this is a less obvious 
discrimination form, it can imply an improper attitude towards certain categories of individuals (e.g. when uniforms are mandatory in a school, students coming from low income families may be disadvantaged);

- Harassment - represents a certain type of "behavior that leads to generating an intimidating, hostile, degrading or offensive environment based on race, nationality, ethnicity, language, religion, social category, convictions, gender, sexual orientation, belonging to a disadvantaged category, age, handicap, status of refugee or asylum seeker or any other criteria" (e.g. making fun of or offending students of other ethnicity, nationality, religion than the majority);

- Victimization - represents "any adverse treatment as a reaction to a legal complaint or action or to relevant institutions, regarding not observing the equal treatment and non-discrimination principle" (e.g. expelling a student with special educational needs following the request from the other students' parents);

- Disposition or order to discriminate - represents the situation where a person or a group usually higher up in the hierarchy orders some other person or group to behave discriminatorily (e.g. parents that advise their children not to interact with children of other ethnicity or with inferior social status);

- Multiple discrimination - entails the simultaneous usage of several discrimination criteria.

The list can be supplemented by structural discrimination which is defined as the situation where "refusing the right of a person is an effect of the way social systems are organiz̨ed" (ISJ Brăila, n.d.: 11). A good example for this type of discrimination is the fact that the core curriculum of the mandatory education period does not include information about the history, values, and traditions of national minorities).

\section{Research Questions/Aims of the research}

The aim of the research was to collect - following a questionnairebased survey - the opinions of teachers working in the pre-university Romanian education, concerning the forms of discrimination found in schools and its classes, their frequency, the teachers' attitudes in relation to such discriminatory practices and the solutions which can be embraced in order to fight and diminish those undesirable behaviors. In addition, the results of the research intended to determine the teachers to adopt a reflective attitude concerning such sensitive issues of discriminatory practices which exist in the Romanian schools. 


\section{Research Methods}

In order to accomplish the abovementioned objectives, a questionnaire with ten items was elaborated, with seven closed, predetermined answers on a five level Likert-scale, two with multiple choice answers and one with dual choice (yes/no). The questionnaire was submitted to a sample of 100 teachers from primary and secondary education levels from Dâmbovița, Prahova and Constanța Counties. Also, for two of the items, the responders were asked to explain their answers so that we can better understand the arguments on which their convictions and attitudes are based, with respect to discriminating practices still present in the Romanian educational system. The data collected were processed initially through quantitative analysis and then correlated with qualitative appreciations resulted from the discussions held with several responders.

\section{Findings and discussions}

The first item of the questionnaire checked the opinion of the responders with respect to the degree they consider the equity, diversity, inclusion and non-discrimination principles observed in the Romanian school (figure 1). Most of the responders considered that such principles are observed to a very large extent (7\%), large extent $(55 \%)$ and moderate extent $(36 \%)$. A small number considers those principles observed to a small extent $(2 \%)$.

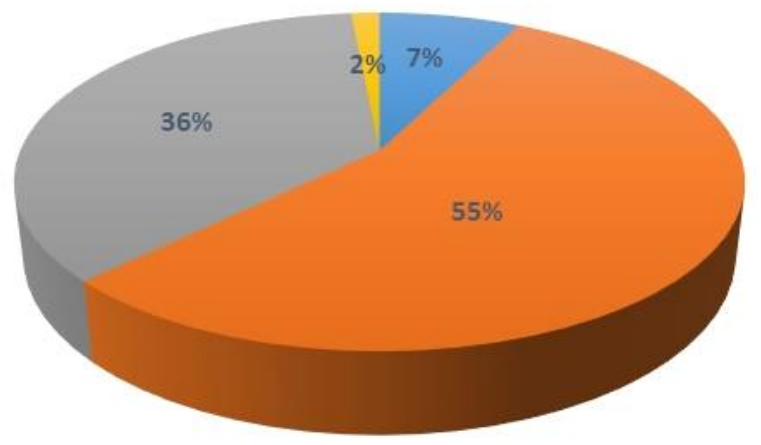

- to a very great extent $\quad$ to a great extent to a moderate extent

w to a small extent $\quad$ to a very small extent 
Figure 1. Teachers' feedback concerning the degree to which the equity, diversity, inclusion and non-discrimination principles are observed in the Romanian schools.

The teachers' arguments that support the data represented in figure 1 can be summarized as follows:

- the existence of a legal framework proper for promoting the equity, diversity, inclusion and non-discrimination principles;

- a qualitative education entails to observe the Unity in Diversity principle;

- the existence of multiple examples of educational good practices used in the Romanian school with respect to non-discrimination;

- the need to work on changing the mentality of all educational actors: teachers, students, parents, local community representatives etc.;

Referring to the most frequent forms of discrimination in the Romanian education system (figure 2), the responders placed discrimination on the basis of social or family situation (in the first place), followed by the discrimination based on physical and/or psychical disabilities and on ethnicity/race. A significant smaller number mentioned discrimination based on religion and even less based on gender. Following the discussions held with several responders on trying to identify the more profound causes of those discriminatory and undesirable behaviors, in the context of promoting the abovementioned principles, we noted that the main explanation resides in the retrograde mentality of the adults (teachers and parents) who cultivate those discriminatory attitudes in children mind, following the still present phenomenon of socio-cultural reproduction of certain social convictions and behaviors that are strongly imbedded in the collective memory of the society/community.

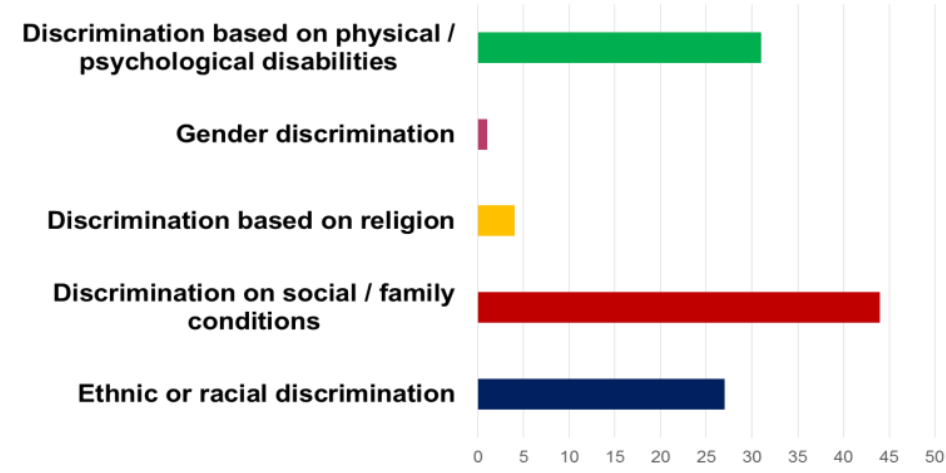

Figure 2. Forms of discrimination met in Romanian schools. 
Following the questionnaire-based research, the teachers were asked how often they use to sanction those students who made pejorative, unfavorable comments related to race, ethnicity, culture, social aspects (figure 3). Thus, $63 \%$ of the responders stated that they do this every time, $22 \%$ quite often, $13 \%$ sometimes, $2 \%$ rarely, and $1 \%$ never. Although the statistical data place the vast majority on the positive part of the evaluation scale, we are obviously wondering why there are still situations where the teacher - representing the main educational agent in the students' personality development and training - does not act to counter this kind of undesirable behaviors. We consider that the causes vary, starting with the teacher's personal convictions and prejudices, continuing with the lack of interest about the formative side of school education, and ending with the fear of those who have uncontrollable reaction concerning such pejorative comments that are often accompanied by discriminatory, disruptive behaviors (physical and/or verbal violence).

Nevertheless, considering the responders' answers gathered in figure 4 , it can be noticed that things are better when it comes to the way they react when somebody humiliates another person or effectively acts in a discriminatory manner.

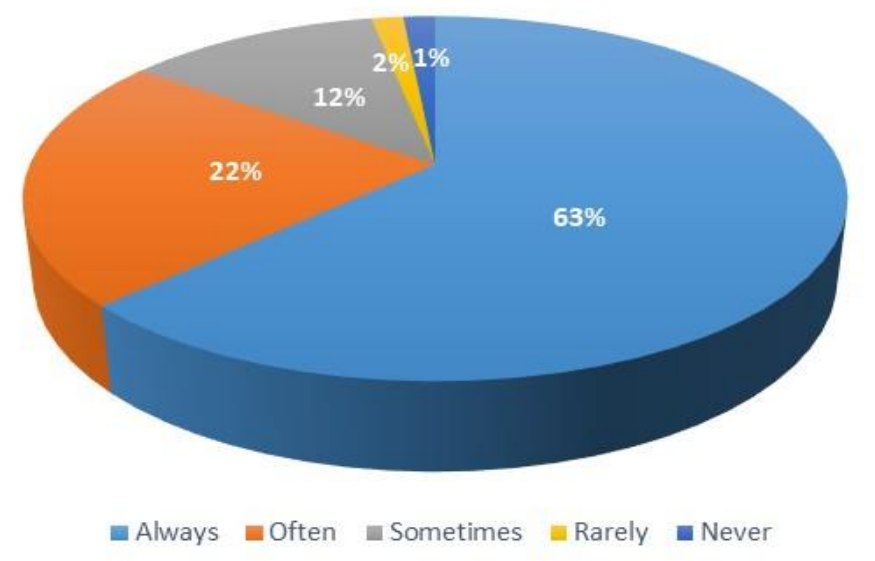

Figure 3. The frequency of the teachers' interventions against those that make pejorative, unfavorable comments related to race, ethnicity, culture, social aspects etc. 


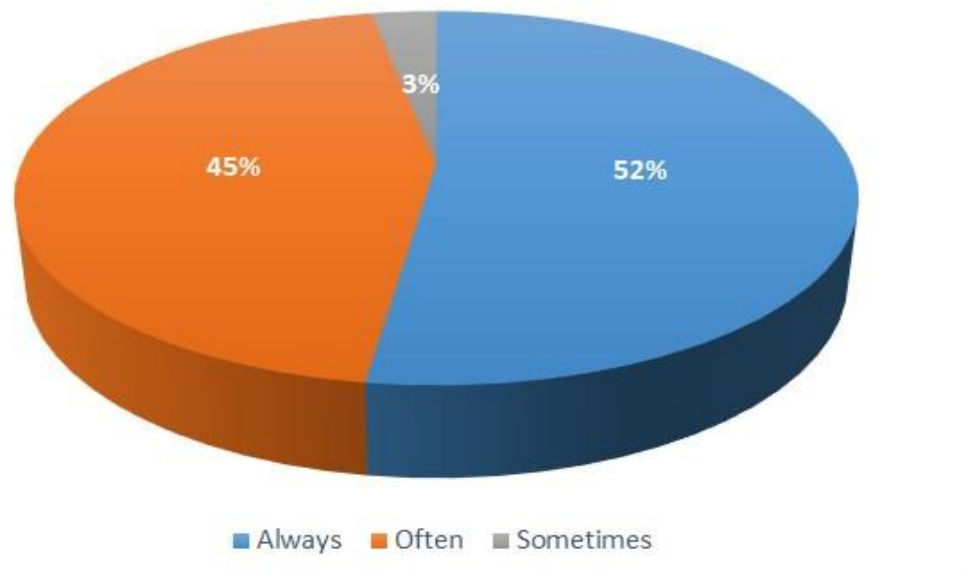

Figure 4. The frequency of teachers' reactions when somebody humiliates another person or effectively acts in a discriminatory manner.

More, $33 \%$ of the responders declared they always used to reflect on the consequences their comments and actions have on various types of students (figure 5). 64\% made those reflections most of the time, and 3\% sometimes. We consider those data correlated with other current research regarding the reflective practices of the Romanian teachers in their professional activity - while the situation is good towards very good (when it comes to declarations), in practice, the reflective attitude of the teachers leaves to be desired, according to students and their parents.

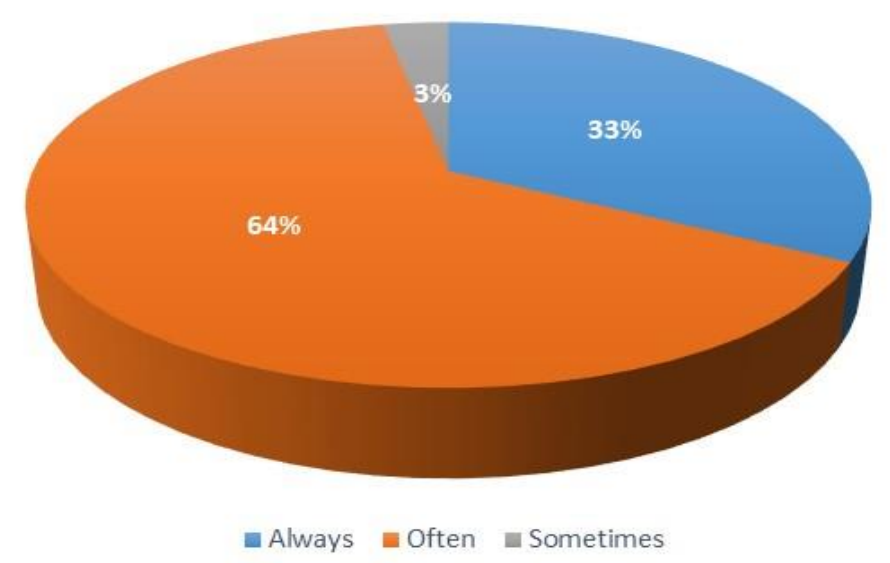

Figure 5. The degree in which the questioned teachers used to reflect on the consequences their comments and actions had on students. 
The answers given to two questions (Do you usually manage to cope with the tendency of being biased or discriminating in your relationship with the students? and Do you consider that you manage to cope with the tendency of being biased or discriminating on evaluating students?) need to be discussed together, due to the fact that both of them are related to the teachers' attitude when it comes to their capacity to cope with the tendency of being biased or discriminating towards their students. Analyzing comparatively, it can be said that teachers cope better with the tendency of being biased when it comes to evaluation than in their relationship with the students. This is explained by the excessive accent placed on school results that are expressed by marks, grades and qualifiers, in the detriment of the aspects that regard the relationship with the students - as efficient communication and getting to know their personality.

Regarding the degree to which they are opened to assume the responsibility of facilitating the integration of students belonging to other cultures, ethnicities, race, religions etc. than the majority, $42 \%$ of the teachers declared they do this always, $51 \%$ most of the time, $6 \%$ sometime, and only 1\% rarely (figure 6). The arguments of the responders in the last two categories are similar to those provided at a previous item regarding their actions with respect to those that make pejorative, unfavorable comments related to race, ethnicity, culture, social aspects etc.

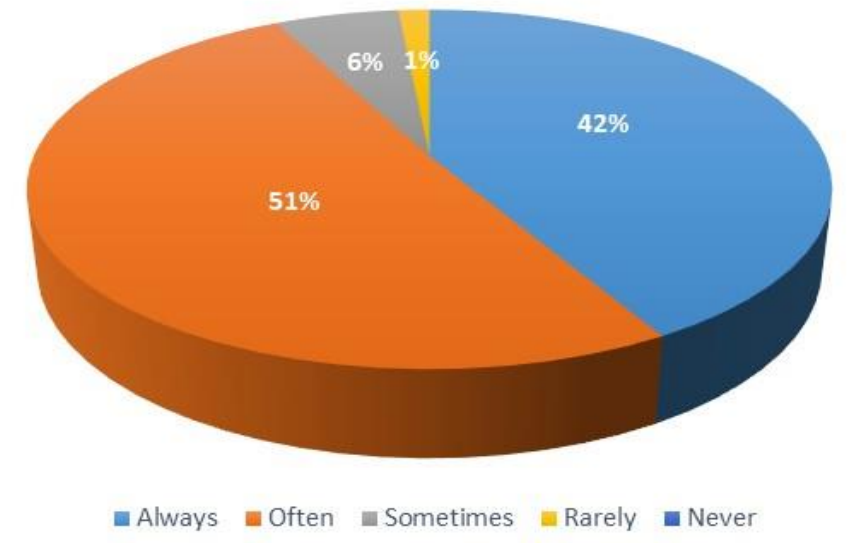

Figure 6. The degree to which the responders are open to assume the responsibility of facilitating the integration of students belonging to other cultures, ethnicities, race, religions etc. than the majority. 
The last item of the questionnaire required the respondents to mention if they regularly design and undergo activities aimed to combat discrimination and promoting cultural, ethnic, religious diversity in their schools. The majority answered positively $(87 \%)$, but there is a percentage alarming, according to our opinion - of $13 \%$ who stated that they do not carry such activities. We consider this as a case of teachers who are not really aware of the formative, educational value of activities regularly performed in all schools, such as homeroom or personal development classes, activities performed during educational projects or partnerships etc., which also have an impact with respect to non-discrimination and inter-culturalism. As examples of such activities, the responders mentioned: Europe Day, Global Education Week, Diversity Week, Tradition Festival, as well as organizing case studies, debates, educational projects and partnerships, volunteering activities, workshops, contests, festivities, self-awareness and personal development activities etc.

\section{Conclusions}

In our opinion, which is corroborated to our responders, adequate measures need to be put in place to prevent and combat discriminatory practices in educational establishments in Romania, such as:

- Organizing certain activities aimed to combat discrimination and promoting cultural, ethnic, religious etc. diversity, in schools and in partnership with other community organizations;

- Organizing continuous training courses for teachers on the topic of diversity, non-discrimination, inter-culturalism etc.;

- Including information about diversity and non-discrimination in the core curriculum;

- Accomplishing a normative/legal framework for sanctioning discriminatory practices, both for students and teachers;

- Systematic monitoring of both curricular and extra-curricular training-educational activities;

- Having subject-matter experts invited to classes;

- Enhancing parent education/training.

All the above-mentioned measures represent activities that "opening the school and therefore the teachers towards inter-cultural education, diversity pedagogy values", as well as "towards promoting non-discriminatory attitudes can only have outstanding formative effects” (Drăghicescu, \& Stăncescu, 2011: 348). 


\section{References}

Consiliul Naţional pentru Combaterea Discriminării (CNCD). (n.d.). Formele discimimării [Forms of discriminaton]. Rerieved from http://cncd.org.ro/formele-discriminarii

Drăghicescu, L. M., \& Stăncescu, I. (2011). Multiculturalism şi educație [Multiculturalism and education]. In V. Dogaru-Ulieru \& L. M. Drăghicescu (Coords.), Educație şi dezvoltare profesională [Education and professional development]. Craiova, Romania: Scrisul Românesc.

Inspectoratul Şcolar Județean Brăila, Casa Corpului Didactic Brăila, Casa Corpului Didactic Prahova, \& Universitatea Petrol-Gaze din Ploieşti (ISJ Brăila). (n.d.). Ghid de bune practici pentru aplicarea principiului nediscriminării în activitătile didactice [Best Practice Guide for the Application of the Nondiscrimination Principle in Educational Activities]. Retrieved from http://www.actored.ro/file comp/documente/ActorED Ghid de bune practici.pdf

Ivasiuc, A., Koreck, M., \& Kovari, R. (2010). Educația interculturală: de la teorie la practică. Implementarea educației interculturale în şcoli multietnice din România [Intercultural education: from theory to practice. Implementation of intercultural education in multiethnic schools in Romania.]. Bucharest, Romania: Agenția de Dezvoltare Comunitară "Împreună”. Retrieved from https://docplayer.net/23970582-Educatia-interculturala-de-la-teorie-lapractica.html

Romanian Parliament. (2006). Legea nr. 324/2006 pentru modificarea şi completarea Ordonanţei Guvernului nr. 137/2000 privind prevenirea şi sancționarea tuturor formelor de discriminare [Law no. 324/2006 amending and supplementing the Government Ordinance no. 137/2000 on the prevention and sanctioning of all forms of discrimination]. Monitorul Oficial al României, 626, 2006, July 20. 